\title{
Intestinal Perforation: A Surgeon's Nightmare Enlightened by Scientific Research
}

\author{
Byung Soh Min \\ Departments of Surgery, Yonsei University College of Medicine, Seoul, Korea
}

See Article on Page 221-227

Intestinal perforation is a surgeon's nightmare that every colorectal surgeon has encountered once in a while, or at least a few times, during his or her career. For some, it is a dramatic victorious memory of a heroic surgeon saving a patient's life after a struggle of several hours while for some it is something never to be remembered. Either way, an intestinal perforation is an unwanted guest that drains a surgeon.

An intestinal perforation has numerous etiologies, and its clinical manifestations range from vague and mild abdominal discomfort to severe life-threatening panperitonitis [1, 2]. Moreover, its outcomes and prognosis are influenced by various factors, including the patient's medical condition and the severity of the disease [3]. Given this variety and ambiguity, the treatment strategy for a patient with an intestinal perforation, including surgical procedure, largely depends upon the surgeon's experience rather than scientific evidence.

Continuing efforts have been made to shed some scientific light on the dark area of ambiguity surrounding the management of a patient with an intestinal perforation $[1,4]$. The current article entitled, "Predictors of Morbidity and Mortality After Surgery for Intestinal Perforation," needs to be read in this context [5]. The authors aimed to reveal factors that could be used to predict the outcome after surgical treatment of a patient with intestinal peritonitis. They retrospectively analyzed 117 patients who had received surgical treatment for intestinal peritonitis. In their data, the most common etiology was an endoscopic complication, followed by diverticulitis, which might reflect a biased patient popu-

Correspondence to: Byung Soh Min, M.D.

Department of Surgery, Yonsei University College of Medicine, 50 Yonsei-ro, Seodaemun-gu, Seoul 03722, Korea

Tel: +82-2-2228-2100, Fax: +82-2-313-8289

E-mail: bsmin@yuhs.ac.kr

(c) 2016 The Korean Society of Coloproctology

This is an open-access article distributed under the terms of the Creative Commons Attribution NonCommercial License (http://creativecommons.org/licenses/by-nc/4.0) which permits unrestricted noncommercial use, distribution, and reproduction in any medium, provided the original work is properly cited. lation. The mortality and the morbidity rates were $12.8 \%$ and $60 \%$, respectively, which, as expected, were relatively low compared to the rates in previous reports. They found female gender, low estimated glomerular filtration rate, and high C-reactive protein to be significant predictive factors for postoperative morbidity. For mortality, shock status and feculent ascites were significant predictive factors.

In a broad sense, an intestinal perforation may be considered as a part of peritonitis, so the maintenance of systemic function is as important as the surgical repair of a mechanical defect of the hollow viscus. In this context, the conclusion of the current article delivers a predictive message. The future direction of further research should include the integration of previous reports to establish treatment strategies based on risk assessment. Based on the results from the current study, the treatment strategy needs to cover critical care medicine, as well as surgical procedures.

\section{CONFLICT OF INTEREST}

No potential conflict of interest relevant to this article was reported.

\section{REFERENCES}

1. Alves A, Panis Y, Mathieu P, Mantion G, Kwiatkowski F, Slim K; Association Française de Chirurgie. Postoperative mortality and morbidity in French patients undergoing colorectal surgery: results of a prospective multicenter study. Arch Surg 2005;140:278-83 .

2. Bielecki K, Kamiński P, Klukowski M. Large bowel perforation: morbidity and mortality. Tech Coloproctol 2002;6:177-82.

3. Biondo S, Ramos E, Deiros M, Ragué JM, De Oca J, Moreno P, et al. Prognostic factors for mortality in left colonic peritonitis: a new scoring system. J Am Coll Surg 2000;191:635-42

4. Le Gall JR, Lemeshow S, Saulnier F. A new Simplified Acute Physiology Score (SAPS II) based on a European/North American multicenter study. JAMA 1993;270:2957-63.

5. Shin R, Lee SM, Sohn BH, Dong Lee W, Song I, Chai YJ, et al. Predictors of morbidity and mortality after surgery for intestinal perforation. Ann Coloproctol 2016;32:221-7. 